\title{
Correlates of Job Satisfaction amongst Quantity Surveyors in Consulting Firms in Lagos, Nigeria
}

Henry Ndubuisi Onukwube, (University of Lagos, Nigeria)

\begin{abstract}
Job satisfaction is the sense of well- being, good feeling and positive mental state that emerge in an incumbent worker when his obtained reward consequent upon his performance is congruent with his equitable reward. Extant literature in other sectors of the economy points to the fact that factors such as poor working conditions, below competitive salaries, a lack of promotional opportunities are some of the factors contributing to employee dissatisfaction. The aim of this study is to ascertain the levels of job satisfaction amongst quantity surveyors in consulting firms in Lagos, Nigeria. Biographical and job descriptive index questionnaires (JDI) were administered to gather the data. The JDI measures job satisfaction on five facets, namely, pay, promotions, supervision, co-workers and the work itself. A total of 100 questionnaires were collected and used for the study. The survey covered quantity surveyors in consulting firms in Lagos and the respondents were selected using stratified random sampling technique. Data collected were analysed using mean item score, spearman rank correlation, correlation matrix, linear regression analysis where appropriate. Findings of the study revealed that the respondents were satisfied with the relationship with co-workers, nature of work and the supervision they receive. Major sources of dissatisfaction are promotion and salaries of the respondents. This finding is a bold step and necessary benchmark for resolving major sources of dissatisfaction among quantity surveyors in consulting firms. The roles of other contextual factors on job satisfaction need to be contemplated for future research.
\end{abstract}

Keywords: Biograghical data, Consulting firms, Correlates, Dissatisfaction, Job descriptive index, Job satisfaction, Nigeria, Quantity Surveyors

\section{Introduction}

Jobs provide a sense of accomplishment and identity. Most employees identify themselves with their jobs. As such, to be happy and satisfied with one's job is very important. Job satisfaction has been defined and measured both as a global construct and as a concept with multiple dimensions or facets (Locke, 1976). Satisfaction with job has always been an area of concern for most organisations, primarily because of the reason that job satisfaction significantly affects major organizational outcomes, such as individual performance, organizational productivity, employee absenteeism and employee turnover. Job satisfaction is commonly interpreted as the intrinsic sense of accomplishment emerged from performing tasks while carrying out one's contractual obligations. Locke (1969) defines job satisfaction as, "Pleasurable emotional state resulting from the appraisal of one's job as achieving or facilitating the achievement of one's job values." Job satisfaction is defined as a collection of feelings that an individual holds towards his or her job (Robbins, 2005). Positive attitudes towards one's job are associated with high levels of job satisfaction. The converse is also true (Bowen et al. 2008). According to Herzberg et al., (1959) work related- attitudes have to do with need satisfaction. People have needs and jobs vary in their ability to fulfill needs. Dipboye et al. (1994) classified job satisfaction theories into three: the two factor theory, comparative theories and cognitive theories. The two factor theory attempted to explain how job satisfaction is influenced by intrinsic factors such as responsibility 
and achievement, while job dissatisfaction is influenced by extrinsic employment factors such as salary and working conditions. Comparative theories involve concepts such as needs and values. Employees evaluate what they get out of their jobs and determine whether this accords with their needs and values while the last focused on cognitive processes. These three theories guide this study. The importance of job satisfaction and motivation to the well-being of the construction industry has been highlighted (Loosemore et al., 2003). The importance lies with its stabilizing effects (reducing lateness, absenteeism and turnover). However, despite the wealth of research into job satisfaction, little research has been undertaken concerning its application to the construction industry(Asad and Dainty, 2005).As Bowen et al., (2008) observed, studies focusing on job satisfaction among quantity surveyors are a relative rarity and in their study they used Maslow's hierarchy of needs in testing the satisfaction level of quantity surveyors. The approach in this study is to use biographical and job descriptive index to test the level of association of these factors with the overall job satisfaction of quantity surveyors. The purpose of this paper is to report on a study examining levels of job satisfaction of professional quantity surveyors in consulting firms in Lagos, Nigeria.

\section{Organisational Determinants and Job Satisfaction}

Several studies have suggested that job satisfaction can be affected by three major factors: (1) factors relating to work settings; (2) factors relating to specific aspects of jobs; and (3) factors associated with the individuals involved (Baron,1986). The organizational determinants examined in this study are work itself, remuneration/pay, supervision, promotion opportunities and co-worker.

\section{The Work Itself and Overall Job Satisfaction}

Locke (1995) postulates that employee job satisfaction is dependent on job satisfaction with the job components, such as the work itself. Robbins et al, (2003) refer to the work itself as "the extent to which the job provides the individual with stimulating tasks, opportunities for learning and growth and the chance to be responsible and accountable for results. Oshagbemi (2000) found a statistically significant relationship between job satisfaction and work itself. Results from other studies conducted indicate that a dimension such as the work itself can result in either job satisfaction or dissatisfaction (Oshagbemi, 1997).

\section{Remuneration/Pay and Overall Job Satisfaction}

Pay satisfaction is of primary concern to both employers and employees. For employees, pay is of obvious importance in terms of satisfying their economic needs. It is important that they are satisfied with their overall pay as this may impact their attitudes and behaviours. Employee dissatisfaction with pay, for instance, can decrease commitment to the job, increase stealing, and catalyze turnover (Currall et al., 2005). According to equity theory, pay satisfaction is based on perceptual and comparative processes (Adams, 1963; Lum et al., 1998). Employees who feel under-rewarded will attempt to restore equity by reducing inputs such as increasing absenteeism, coming late to work, taking longer breaks, and decreasing productivity, or by leaving the organization, all of which are very costly for an employer (Greenberg, 1990). Research appears to be equivocal regarding the influence of pay on job satisfaction. In a study conducted by Oshagbemi (2000) amongst United Kingdom academics, a statistically significant relationship was established between pay and job satisfaction. However, a study conducted by Young et al., (1998) among public sector employees failed to find any significant relationship between the two variables.

Onukwube, H N (2012) 'Correlates of job satisfaction amongst quantity surveyors in consulting firms in Lagos, Nigeria', Australasian Journal of Construction Economics and Building, 12 (2) 43-54 


\section{Supervision and Overall Job Satisfaction}

Supervision forms a pivotal role relating to job satisfaction in terms of the ability of the supervisor to provide emotional/technical support and guidance with work related tasks (Robbins et al, 2003). A relationship with immediate supervisor is an important antecedent of employee's job satisfaction (Dupre and Day, 2007). The consideration a supervisor has for his/her subordinates' feelings, well being, and contributions are an important predictor of job satisfaction ((McCormack et al. 2006; Gagnon and Judd, 2004).Gagnon and Judd (2004) found that employees with supervisors displaying democratic management styles experienced higher levels of job satisfaction compared to those who had supervisors who exhibited autocratic leadership style.

\section{Promotion Opportunities and Overall Job Satisfaction}

A number of researchers are of the opinion that job satisfaction is strongly related to opportunities for promotion (Pergamit \& Veum, 1999). This view is supported by Ellickson and Logsdon (2002) in their study on municipal government workers where they established a statistically significant relationship between promotion and job satisfaction. Bowen \& Cattel (2008) found a positive relationship between promotion and job satisfaction. Keitner and Kinicki (2001) however, state that the positive relationship between promotion and job satisfaction is dependent on perceived equity by employees.

\section{Co-Workers and Overall Job Satisfaction}

Social network theory has shown that social support from co-worker networks serves as a resource that affects job satisfaction (Bonache, 2005) A number of authors maintain that having friendly and supportive colleagues contribute to increased job satisfaction (Kreitner \& Kinicki, 2001). By the same token, Raabe and Beehr (2003) argue that co-worker relationships have an important influence on employee organizational commitment that results from employee job satisfaction. Indeed, close relationships with one's co-workers increase job satisfaction particularly in a situation where co-workers are regarded as friends, as a support system (McNeese-Smith and Nazarey, 2001).

\section{Job Satisfaction and Personal Characteristics}

Studies have indicated that personal characteristics affect job satisfaction in different and complex ways. Among these personal characteristics is gender, age, education, and work experience.

\section{Gender and Job Satisfaction}

Several studies conducted with regard to the relationship between gender and job satisfaction have yielded contradictory results (Chiu, 1998). Several studies have found women to be more satisfied than men (Sloane \& Williams, 2000). Tang and Talpade (1999) found that men tend to have higher satisfaction with remuneration in relation to females, while females tended to have higher satisfaction with co-workers than males. Oshagbemi (2000) however, failed to find that gender affects job satisfaction.

\section{Age and Job Satisfaction}

Several researchers have examined the link between age and job satisfaction. The findings of these studies have been contradictory, with researchers reporting five different types of relationships. For instance, Hunt and Saul (1975) reported that there is a positive linear relationship between age and job satisfaction. A negative linear relationship was reported by Muchinsky (1978), and a U-shaped relationship was described by Clark et al. (1996) and such a relationship is strong at the beginning, but keeps declining till mid 30s and gradually increasing

Onukwube, H N (2012) 'Correlates of job satisfaction amongst quantity surveyors in consulting firms in Lagos, Nigeria', Australasian Journal of Construction Economics and Building, 12 (2) 43-54 
till 60s.Positive significant relationship was discovered by Oshagbemi (2003), yet Ronen (1978) found no significant relations. Researchers have also found that older employees are better able to balance personal needs and jobs/organizations than are younger employees (Lewis, 1991). In addition, older employees are more likely to cognitively justify remaining in the organization, as they may have limited alternative employment opportunities and greater costs than do younger employees. As a result, older employees are likely to develop more positive attitudes toward their jobs.

\section{Education and Job Satisfaction}

Studies have found positive relationships between levels of education and job satisfaction. A study conducted by (Kh metle, 2003) amongst Kuwaiti women employed in a public government sector environment, showed that a strong relationship existed between the level of education and overall job satisfaction. According to Ting (1997), researchers have argued that employees with more education can improve job satisfaction by rationalizing available alternatives for changing jobs or leaving employers. Other researchers have maintained that more educated workers have a greater number of job alternatives and, thus, are less likely to become trapped in any job or organization. As a result, they are less likely to develop great affection toward their job and organization (Ting, 1997). In addition, educated workers may have expectations that their employers may not be able to meet. This affects attitudes toward jobs and organizations, either positively or negatively.

\section{Experience and Job Satisfaction}

Research conducted by (Oshagbemi, 2003, Clarke et al, 1996) conformed that there is significant relationship between experience and job satisfaction. Oshagbemi (2000) attribute the increase in job satisfaction over the length of time to factors such as job stability and opportunities for promotion. In his study of the relationships between personal characteristics and job satisfaction of Turkish workers, Bilgic (1998) indicated that the contribution of experience to good feelings toward one's job is positive. His findings indicated that people with more work experience have more respect for their jobs and can apply their experience to their job; they were also more likely to enjoy the physical work environment (Bilgic, 1998).

\section{Hypotheses of the Study}

The study postulates the following null hypotheses

$\mathrm{HOa}$ : That there is no positive significant relationship between facets of job satisfaction and overall job satisfaction of quantity surveyors

HOb: Male quantity surveyors in consultancy firms will not be more satisfied with their jobs than with their female counterparts

HOc: Older quantity surveyors in consultancy firms will not be more satisfied with their jobs than younger quantity surveyors

H0d: Quantity Surveyors who have postgraduate degrees are not more satisfied than quantity surveyors with a bachelor's degree or less education

HOe: Years of experiences will not have a significant positive impact on the job satisfaction of quantity surveyors

The positive hypotheses is used to test the null hypotheses

Onukwube, H N (2012) 'Correlates of job satisfaction amongst quantity surveyors in consulting firms in Lagos, Nigeria', Australasian Journal of Construction Economics and Building, 12 (2) 43-54 


\section{Methods}

The target population for this study comprised quantity surveyors in consultancy firms in Lagos state, Nigeria. Research into correlates of job satisfaction is scanty in quantity surveying profession in Nigeria; hence this is an attempt to contribute to knowledge to fill this gap. Lagos state was chosen as the research area because it is a cosmopolitan town with the largest concentration of practicing quantity surveyors domicile in the state. A simple random sampling technique was adopted for consultancy firms. The firms were sampled from a list of registered quantity surveying firms with the Nigerian institute of quantity surveyors. The population was stratified according to fellows, corporate and non-corporate members. A total of 125 questionnaires were distributed, and 100 were returned, representing $80.0 \%$ response rate.

\section{Measures}

\section{Facets of Job Satisfaction}

The JDI is one of the most popular measures of job satisfaction and has been found to produce highly reliable results. It measures facets of job satisfaction in the area of supervision, work itself, co-worker relationship, pay and promotion. The abridged version of the JDI (Stanton et al., 2001) was used to assess the five facets of job satisfaction: satisfaction with pay, promotion opportunities, coworkers, supervision, and the work itself. Internal consistency reliability was acceptable $(\alpha=.85, .81, .91, .90$, and .83 respectively). The measure contained 25 descriptor items (five for each facet). Items were answered on a 5-point Likert scale, a summed composite of the responses was calculated, with higher scores indicating greater satisfaction. Scores for each facet ranged from a low of 0 to a high of 25 .

\section{Job Satisfaction in General}

The Job in General Scale (JIG).The JIG was constructed to reflect the global long term evaluation of the job (Balzer et al., 1997). This measure contained 18 descriptor items using the same presentation format and 5-Point Likert scale as the JDI. Sample items included as advocated, a summed composite of the responses are calculated, with higher scores indicating greater overall satisfaction. Scores for this scale ranged from a low of 0 to a high of 90 . The internal consistency reliability was acceptable $(\alpha=.93)$.

\section{Personal Characteristics}

The abridged version of the demographic instrument (Dirani and Kuchunke, 2011), was used to measure gender ( 2 items), age ( 3 items), Education ( 3 items) and Experience (2 items).

\section{Results and Discussion}

\section{Demographic Data}

From the biographical information of the respondents presented in Table 1, 73 percent of the respondents are male while 27 percent are female. This result shows that this is a male dominated profession.

In terms of the age distribution of the respondents, majority of the respondents, $40 \%$ are forty one years and above. As regards educational qualification of the respondents, $65 \%$ of them had first degree or equivalent, while $32 \%$ had second degrees and the remaining $3 \%$ had doctorate degrees. In terms of the professional qualification of the respondents, $73 \%$ of the respondents are professionally qualified and this means that their contribution in this research will be useful. As regards the working experience of the respondents, $60 \%$ of the respondents had not more than ten years experience while $40 \%$ had more than ten years experience. This result may be because most consulting firms do not pay an economic wage, hence turnover intentions is usually high.

Onukwube, H N (2012) 'Correlates of job satisfaction amongst quantity surveyors in consulting firms in Lagos, Nigeria', Australasian Journal of Construction Economics and Building, 12 (2) 43-54 


\begin{tabular}{|l|c|c|c|c|}
\hline \multicolumn{1}{|c|}{ Sex of Respondents } & Freq. & Cum. Freq. & Percentage & Cum. Percentage \\
\hline Male & 73 & 73 & $73 \%$ & $73 \%$ \\
\hline Female & 27 & 100 & $27 \%$ & $100 \%$ \\
\hline Total & 100 & & & \\
\hline \multicolumn{1}{|c|}{ Age of Respondents } & & & & $25 \%$ \\
\hline Less than 30 years & 25 & 25 & $25 \%$ & $60 \%$ \\
\hline $31-40$ years & 35 & 60 & $35 \%$ & $100 \%$ \\
\hline 41 years and above & 40 & 40 & $40 \%$ & \\
\hline Total & 100 & & & $65 \%$ \\
\hline Educational Qualification & & & & $97 \%$ \\
\hline HND/B.Sc & 65 & 65 & $65 \%$ & $100 \%$ \\
\hline M.Sc & 32 & 97 & $32 \%$ & \\
\hline Ph.D & 3 & 100 & $3 \%$ & \\
\hline Total & 100 & & & $27 \%$ \\
\hline Professional Qualification & & & & $82 \%$ \\
\hline Non qualified members & 27 & 27 & $27 \%$ & $100 \%$ \\
\hline MNIQS & 55 & 82 & $55 \%$ & \\
\hline FNIQS & 18 & 100 & $18 \%$ & \\
\hline Total & 100 & & & \\
\hline
\end{tabular}

Table 1 Demographic Profile of Respondents

\section{Relationship between Overall Job Satisfaction and Facets of Job Satisfaction}

Table 2 reveals descriptive statistics (means and standard deviations) and Pearson correlation coefficients of the variables. There are several interesting findings that should be noted. The correlation coefficient indicates that all the five facets of job satisfaction are positively and significantly related with overall job satisfaction. Hypothesis H1a: That there is positive significant relationship between facets of job satisfaction and overall job satisfaction of quantity surveyors is strongly supported by this result. This finding agrees with previous research (Locke, 1995; Oshagbemi, 2000; Bowen \& Cattel, 2008; and Bonache, 2005) with regards the relationship between pay and overall job satisfaction, this result contradicts the findings of Young et al. (1998) who failed to find any significant relationship between the two variables.

\begin{tabular}{|l|l|l|l|l|l|l|l|l|c|}
\hline \multicolumn{1}{|c|}{ Variables } & Range & \multicolumn{1}{c|}{$\mathbf{M}$} & \multicolumn{1}{c|}{ SD } & \multicolumn{1}{c|}{$\mathbf{1}$} & $\mathbf{2}$ & $\mathbf{3}$ & $\mathbf{4}$ & $\mathbf{5}$ & $\mathbf{6}$ \\
\hline $\begin{array}{l}\text { Job } \\
\text { satisfaction }\end{array}$ & $0-90$ & 72.90 & 60.79 & $(0.93)$ & & & & & \\
\hline Work itself & $0-25$ & 20.42 & 12.12 & $0.73^{\star *}$ & $(0.83)$ & & & & \\
\hline Pay & 0.25 & 9.62 & 5.67 & $0.47^{\star *}$ & $0.40^{* *}$ & $(0.85)$ & & & \\
\hline Promotion & $0-25$ & 10.10 & 6.26 & $0.44^{\star *}$ & $0.34^{\star *}$ & $0.33^{\star *}$ & $(0.81)$ & & \\
\hline Supervisor & $0-25$ & 16.22 & 8.94 & $0.57^{\star *}$ & $0.39^{* *}$ & $0.32^{* *}$ & $0.41^{* *}$ & $(0.91)$ & \\
\hline Co-worker & 0.25 & 20.71 & 12.80 & $0.52^{\star *}$ & $0.44^{\star *}$ & $0.27^{\star *}$ & $0.23^{\star *}$ & $0.37^{\star *}$ & $(0.90)$ \\
\hline
\end{tabular}

Table 2 means, standard deviations and correlations for overall job satisfaction and JDI facets of job satisfaction

$\mathrm{N}=100$, figures in parentheses are alpha reliabilities for each scale, ${ }^{* *}=\mathrm{P}<0.001$

Onukwube, H N (2012) 'Correlates of job satisfaction amongst quantity surveyors in consulting firms in Lagos, Nigeria', Australasian Journal of Construction Economics and Building, 12 (2) 43-54 
Presented in Table 3 are the mean differences in job satisfaction between male and female quantity surveyors. The data in Table 3 show that male quantity surveyors have higher mean scores in the job satisfaction subscales of pay, promotion, and supervision than do female quantity surveyors. On the other hand, female quantity surveyors have higher mean scores on job satisfaction subscales of the work itself and co-workers. With regard to overall satisfaction, both male and female quantity surveyors tend to be equally satisfied with their jobs. Based on this finding, one can suggest that since mean scores of male quantity surveyors were higher in pay, promotions, supervision, and overall job satisfaction than were the mean scores of female quantity surveyors, male quantity surveyors seemed to be more satisfied with these facets of job satisfaction than were female quantity surveyors. From this information, Hypothesis H1b: Male quantity surveyors in consultancy firms will be more satisfied with their jobs than will their female counterparts is supported. This result is in agreement with Tang and Talpade (1999) who found that men tend to have higher satisfaction with remuneration in relation to females, while females tended to have higher satisfaction with co-workers than males.

\begin{tabular}{|l|c|c|c|}
\hline \multicolumn{1}{|c|}{$\begin{array}{c}\text { Job satisfaction areas } \\
\text { (mean scores) }\end{array}$} & $\begin{array}{c}\text { Male } \\
\mathbf{( N = 7 3 )}\end{array}$ & $\begin{array}{c}\text { Female } \\
(\mathbf{N}=\mathbf{2 7})\end{array}$ & P-value \\
\hline The work itself & 31.6167 & 34.5446 & $0.001^{*}$ \\
\hline Pay & 37.2400 & 31.8291 & $0.000^{*}$ \\
\hline Supervision & 40.4337 & 29.6773 & $0.012^{*}$ \\
\hline Promotion & 39.2088 & 28.9182 & $0.014^{*}$ \\
\hline Co-workers & 26.2269 & 35.2032 & $0.005^{*}$ \\
\hline Overall job satisfaction & 33.3201 & 31.7245 & $0.021^{*}$ \\
\hline
\end{tabular}

Table 3 Differences in Job satisfaction means based on Gender ( $N=100)$ (T-test)

* Denotes significant differences among groups at the 0.05 level

One-way analysis of variance (ANOVA) was conducted to determine whether differences in job satisfaction exist among the quantity surveyors surveyed in this research. Table 4 indicates that the mean scores for quantity surveyor 31 through 40 years of age (mean, 36.5778) and quantity surveyors 41 years or older (mean, 37.1992) with respect to satisfaction with pay were greater (at the .05 level of significance). Thus, quantity surveyors 31 years and older were more satisfied with their pay than were their counterparts, aged 30 years or younger (mean, 27.5443).

\begin{tabular}{|c|c|c|c|c|}
\hline $\begin{array}{c}\text { Age groups } \\
\text { Job Satisfaction Area } \\
\text { (mean scores) }\end{array}$ & $\leq 30$ & $31-40$ & $\geq 41$ & $P$ - value \\
\hline The work itself & 32.6552 & 37.8882 & 36.4458 & 0.1633 \\
\hline Pay & 27.5443 & 36.5778 & 37.1992 & $0.0204^{*}$ \\
\hline Supervisor & 19.8886 & 26.9556 & 28.8188 & 0.1645 \\
\hline Promotion & 26.9334 & 28.9095 & 29.2775 & 0.1796 \\
\hline Co-workers & 35.3700 & 35.4544 & 34.7808 & 0.1958 \\
\hline Overall job satisfaction & 27.2210 & 37.1610 & 32.4445 & $0.0105^{*}$ \\
\hline
\end{tabular}

Table 4 Differences in Job satisfaction means based on age $(n=100)$ (One-Way ANOVA)

* Denotes significant differences among groups at the 0.05 level

The findings in Table 4 indicate that significant differences were found in the overall job satisfaction of quantity surveyors 30 years old or younger and quantity surveyors 31 years and

Onukwube, H N (2012) 'Correlates of job satisfaction amongst quantity surveyors in consulting firms in Lagos, Nigeria', Australasian Journal of Construction Economics and Building, 12 (2) 43-54 
older, and no significant differences were found with respect to satisfaction with the work itself, promotion, co-workers, and supervision. From these findings, Hypothesis H1c: Older quantity surveyors in consultancy firms will be more satisfied with their jobs than younger quantity surveyors is supported. These findings align with earlier studies (Lewis, 1991) this could imply that the quantity surveying consultancy firms appreciates older workers and fosters a challenging, respected, and creative work environment that gives older workers a sense of accomplishment. Also, satisfaction with the subscale of pay could imply that older quantity surveyors are better paid and their organizations value their wisdom, experience, and expertise, whereas younger quantity surveyors think that their expertise is not appreciated and that they are poorly paid. On the other hand, the results of this study contradict the findings of Clark and colleagues (1996), who asserted that the age-job satisfaction relationship of British employees is $U$ shaped.

Table 5 indicates that there were significant differences among quantity surveyors with regard to their education level on the subsection of present pay and their overall job satisfaction at the 0.05 level of significance. Quantity surveyors with postgraduate degrees were significantly more satisfied with their present job, pay, promotion, supervision, co-workers, and overall job satisfaction than were quantity surveyors with bachelor's degrees at the 0.05 level. Hypothesis H1d: Quantity Surveyors who have postgraduate degrees are more satisfied than quantity surveyors with a bachelor's degree or less education is supported.

\begin{tabular}{|l|c|c|c|c|}
\hline \multicolumn{1}{|c|}{$\begin{array}{c}\text { Educational qualification } \\
\begin{array}{c}\text { Job Satisfaction Areas } \\
\text { Mean scores }\end{array}\end{array}$} & HND or B.Sc & M.Sc & Ph.D & P - value \\
\hline The work itself & 30.15 & 31.82 & 35.08 & $0.033^{*}$ \\
\hline Pay & 24.74 & 33.27 & 36.20 & $0.000^{*}$ \\
\hline Supervisor & 24.23 & 27.90 & 29.47 & $0.003^{*}$ \\
\hline Promotion & 17.93 & 24.75 & 35.18 & $0.011^{*}$ \\
\hline Co-workers & 32.71 & 34.54 & 37.30 & $0.050^{*}$ \\
\hline Overall job satisfaction & 27.35 & 30.65 & 32.64 & $0.002^{*}$ \\
\hline
\end{tabular}

Table 5 Differences in Job satisfaction means based on Education $(n=100)$ (One-Way ANOVA)

* Denotes significant differences among groups at the 0.05 level

Table 6 indicates that there were significant differences among quantity surveyors with regard to some facets of job satisfaction, such as satisfaction with the work itself, pay, supervisor, and coworkers at the 0.05 level of significance. No statistical differences were obtained with a 0.5 level of significance between satisfaction with promotion and overall job satisfaction. With respect to pay and satisfaction, those quantity surveyors who had ten or more years of experience were more satisfied in these areas than were quantity surveyors with fewer than ten years' experience .From these findings, Hypothesis H1e: Years of experience will have a significant positive impact on the job satisfaction of quantity surveyors is supported. The results of this study are consistent with the findings of Bilgic (1998) and Maghradi (1999). These findings could indicate that people with more work experience have more respect for their jobs, can apply their experience to their jobs, and are skilled and successful in doing their jobs. If they are effective and efficient in doing their jobs, they are likely to be paid more and are more likely to enjoy their supervisors, coworkers, and physical work environment.

Onukwube, H N (2012) 'Correlates of job satisfaction amongst quantity surveyors in consulting firms in Lagos, Nigeria', Australasian Journal of Construction Economics and Building, 12 (2) 43-54 


\begin{tabular}{|l|c|c|c|}
\hline \multicolumn{1}{|c|}{$\begin{array}{c}\text { Years of Experience } \\
\text { Job Satisfaction Areas } \\
\text { (mean scores) }\end{array}$} & $\mathbf{1 0}$ & $\geq \mathbf{1 0}$ & P - value \\
\hline The work itself & 32.5152 & 38.4452 & $0.003^{*}$ \\
\hline Pay & 30.8402 & 35.9291 & $0.020^{*}$ \\
\hline Supervisor & 23.8336 & 29.7713 & 0.766 \\
\hline Promotion & 19.8120 & 20.2287 & $0.036^{*}$ \\
\hline Co-workers & 36.3662 & 35.9102 & $0.005^{*}$ \\
\hline Overall job satisfaction & 31.5210 & 32.3440 & 0.123 \\
\hline
\end{tabular}

Table 6 Differences in job satisfaction means based on years of experience $(n=100)$ (t-test)

* Denotes significant differences among groups at the 0.05 level.

\section{Conclusions}

The purpose of this paper is to report on a study examining levels of job satisfaction of professional quantity surveyors in consulting firms in Lagos, Nigeria. The key findings of the study were that job satisfaction is strongly correlated to facets of job satisfaction and the personal characteristics of quantity surveyors. The results of the study suggest that job satisfaction variables are not unidirectional in their effects. For example, the job itself can be a source of both satisfaction and dissatisfaction. Any particular aspect of job satisfaction (satisfaction with the job itself, pay, promotion, supervision, coworkers, and overall job satisfaction) may have significant impact on a quantity surveyor's overall job satisfaction, and vice versa. The implication of this finding is that decision-makers should be mindful of factors that contribute to job dissatisfaction, and attempt to improve them to achieve greater job satisfaction .With regard to age, the findings of this study tend to support the assumption that job satisfaction increases with age. It can also be concluded that older quantity surveyors experience greater job satisfaction than do younger quantity surveyors, because they have job experience, tenure, job security, and higher income, as well as maturity that only age can bring. Implications of this finding are that management should focus its efforts on improving the job satisfaction of younger and newly employed quantity surveyors by developing management training programs, workshops, financial incentives, and other non-work-related activities that would encourage and support them to stay and grow with the organization. The data for this study indicate that educational achievement affects job satisfaction. The implication of this finding is for organizations to encourage quantity surveyors to further their education. Results also show that male and female quantity surveyors had significantly different levels of satisfaction. Male quantity surveyors were more satisfied with their jobs than were their female counterparts. Management should strive to encourage more women into management positions by trying to enhance job satisfaction; this can be done by furthering their education, establishing a comparable pay policy, creating equal opportunity for promotion, and improving work environment for both sexes.

\section{Recommendations}

The result of this study shows a statistically significant relationship between job satisfaction of quantity surveyors and works itself. Hence in support of Robbins et al.(2003) work, it is important for top management of consulting quantity surveying firms to provide stimulating tasks, opportunities for learning and growth to quantity surveyors in their employment. A statistically significant relationship was established between pay and job satisfaction of quantity surveyors. This agrees with result of study done by Oshagbemi (2000), hence it is important that

Onukwube, H N (2012) 'Correlates of job satisfaction amongst quantity surveyors in consulting firms in Lagos, Nigeria', Australasian Journal of Construction Economics and Building, 12 (2) 43-54 
consulting quantity surveying firms pay quantity surveyors in their employment an equitable pay as this will help them to satisfy their economic needs and enhance their commitment to duty. The association between supervision and job satisfaction of quantity surveyors is statistically significant. Hence it is strongly recommended that consulting quantity surveying firms should display of research result of McCormack et al ;(2006). Promotions should be based on merit and performance. Promotions would then be perceived by quantity surveyors as fair and equitable and would encourage productivity and enhance job satisfaction. Since this study established a statistically significant relationship between co-worker and job satisfaction of quantity surveyors, it is important that consulting quantity surveying firms should always educate their employees on the importance of establishing positive relationship in the work place. Since educational attainment predicts job satisfaction, quantity surveyors should be encouraged to further their education. This can be achieved by offering in-service courses, workshops, self/independent study programs and other types of educational programs that enhance skills and cognitive abilities. It is recommended that pay increases be aligned with the cost of living. The roles of other contextual factors on job satisfaction need to be contemplated for future research.

\section{References}

Adams, J. S. (1963) 'Toward an Understanding of Inequity', Journal of Abnormal and Social Psychology, 67, 422-436

Asad, S. and Dainty, A. R. J. (2005) 'Job motivational factors from disparate occupational groups within the UK construction sector: a comparative analysis,' Journal of Construction Research, 6 (2), 223-36

Balzer, W. K. Kihm, J. A. Smith, P.C. Irwin, J. L. Bachiochi, P. D. and Robie, C. (1997) User's manual for the the Job in General (JIG) scales, Bowling Green, OH: Bowling Green State

Baron, R. (1986) Behaviour in Organizations, Newton, MA: Allyn and Bacon

Bilgic, R. (1998) 'The relationship between job satisfaction and personal characteristic of Turkish workers,' The Journal of Psychology, 132 (1), 549-57

Bonache, J. (2005) 'Job satisfaction among expatriates, repatriates and domestic employees: the perceived impact of international assignments on work-related variables,' Personnel Review, 34, 110-124

Bowen, P. A, Cattel, K. S, Distiller, G and Edwards, P .J. (2008) 'Job Satisfaction of South African Quantity Surveyors: An Empirical Study,' Construction Management and Economics, 26, 765-780

Chiu, C. (1998) 'Do Professional women have lower job satisfaction than professional men? Lawyers as a case study,' Sex roles, 38 (7), 521-537

Clark, A. Oswald, A. and Warr, P. (1996) 'Is job satisfaction U-shaped in age?', Journal of Occupational and Organizational Psychology, 69, 57-81

Currall, S. C., Towler, A. Judge, T. A. and Kohn, L. (2005) 'Pay Satisfaction and Organizational Outcomes', Personnel Psychology, 58 (3), 613-640

Dipboye, R. L., Smith, C. S. and Howell, W. C. (1994) Understanding Industrial and Organizational Psychology: An Integrated Approach, Orlando: Harcourt Brace \& Company

Diran, K. M. and Kuchinke, K. P. (2011) 'Testing the correlations and investigating the effects of Demographic variables in the Lebanese banking sector', The international journal of human resource management, 22 (5), 1180 - 1202

Onukwube, H N (2012) 'Correlates of job satisfaction amongst quantity surveyors in consulting firms in Lagos, Nigeria', Australasian Journal of Construction Economics and Building, 12 (2) 43-54 
Dupre, K. and Day, A. (2007) 'The effects of supportive management and job quality on the turnover intentions and health of military personnel,' Human Resources Management, 46, 185201

Gagnon, M. and Judd, M. (2004) 'Outcomes of perceived supervisor support for wood production employees,' Forest Products Journal, 54, 172-17

Greenberg, J. (1990) 'Yesterday, Today, and Tomorrow,' Journal of Management, 16 (2), 399-432

Herzberg, F. Mausner, B. and Snyderman, B. B. (1959) The motivation to work, New York: John Wiley \& Sons

Hunt, J .S. and Saul, P .N. (1975) 'The relationship of age, tenure, and job satisfaction in males and females,' Academy of Management Journal, 18, 690-702

Kh metle, M. (2003) 'The Impact of Education on Attitudes of Female Government Employees,' The Journal of Management Development, 22 (7), 603-626

Kreitner, R. and Kinicki, A. (2001) Organizational Behaviour, $5^{\text {th }}$ ed, New York, MC Graw Hill Inc Lewis, G.B. (1991) 'Turnover and the quest crisis in the federal civil service,' Public Administrative Review, 51, 145-55

Locke E .A. (1969) 'Job Satisfaction and Job Performance: A Theoretical Analysis,' Organizational Behavior and Human Performance, 4 (1), 309-336

Locke, E .A. (1976) 'The Nature and Causes of Job Satisfaction,' In M. D. Dunnette (Ed.), Handbook of Industrial and Organizational Psychology, Chicago, 1297-1349

Loosemore, M. Dainty, A. and Lingard, H. (2003) Human Resource Management in Construction Projects: Strategic and Operational Approaches, London: Spon Press

Lum, L. J. Kervin, K. Clark, F. and Sirola, W. (1998) 'Explaining Nursing Turnover Intent: Job Satisfaction, Pay Satisfaction, or Organizational Commitment?', Journal of Organizational Behaviour, 19, 305-320

McCormack, D. Casimir, G. Djurkovic, N. and Yang, L. (2006) 'The concurrent effects of, satisfaction with supervisors, and satisfaction with co-workers on affective commitment among school teachers in China', International Journal of Conflict Management, 17, 316-331

McNeese-Smith, D. and Nazarey, M. (2001) 'A nursing shortage: building organizational commitment among nurses,' Journal of Healthcare Management, 46, 173-87

Milkovich, G .T. and Newman, J. (2008) Compensation, $8^{\text {th }}$ ed, New York, McGraw-Hill Irwin

Muchinsky, P. M. (1978) 'Age and job facet satisfaction: A conceptual reconsideration,' Aging and Work, 1, 175-9

Oshagbemi, T. (1997) 'The influence of rank on the job satisfaction of organizational members', Journal of Managerial Psychology, 12 (8), 511-9

Oshagbemi, T. (2000) 'Gender differences in the job satisfaction of university teachers', Women in Management Review, 15 (7), 331-43

Oshagbemi, T. (2003) 'Personal correlates of job satisfaction: Empirical evidence from UK universities,' International Psychology, $2^{\text {nd }}$ ed, Consulting Psychological Press, Palo Alto, CA, 485-550

Pergamit, M. R. and Veum, J .R. (1999) 'what is promotion?', Industrial \& Labour Relation Review, 52 (4), 21

Onukwube, H N (2012) 'Correlates of job satisfaction amongst quantity surveyors in consulting firms in Lagos, Nigeria', Australasian Journal of Construction Economics and Building, 12 (2) 43-54 
Raabe, B. and Beehr, T. (2003) 'Formal mentoring versus supervisor and coworker relationships differences in perceptions and impact', Journal of Organizational Behaviour, 24, 271-292

Robbins, S .P. (2003) Organizational behavior, Upper Saddle River, Prentice-Hall

Ronen, S. (1978) 'Job satisfaction and the neglected variable of job seniority', Human Relations, 31 (4), 297-308

Spector, P. E. (2006) Industrial and organizational psychology, $4^{\text {th }}$ ed, USA John Willey \& Sons

Sloane, P .and Williams, H. (2000) 'Job satisfaction, comparison earnings, and gender,' Labour, 14 (3), 473-502

Tang, T. L. and Talpade, M. (1999) 'Sex Differences in Satisfaction with pay and co-workers,' Personnel Journal, 27 (3), 1-5

Ting, Y. (1997) 'Determinants of job satisfaction of federal government employees,' Public Personnel Management, 9, 1-18

Young, B.S., Worchel, S. \& Woehr, W.D.J. (1998) 'Organizational Commitment among Public Service Employees,' Personnel Journal, 27 (3), 339-348 